УДК 65.014 .1

Немченко Ганна, асистент,

Одеська національна академія харчових технологій, кафедра управління бізнесом, м. Одеса; ORCID ID 0000-0003-0407-3744 email: lady.anna.cat@gmail.com

Колеснікова Катерина, кандидат економічних наук, доцент, Одеська національна академія харчових технологій, кафедра менеджменту та логістики, м. Одеса; ORCID ID 0000-0001-6954-6819 email:ekolesnikova.od@gmail.com

Бондар Вікторія, кандидат економічних наук, Одеська національна академія харчових технологій, кафедра менеджменту та логістики, м. Одеса; ORCID ID 0000-0002-0419-6579 email:bondarv1801@gmail.com

https://doi.org/10.29038/2411-4014-2020-02-107-113

\title{
ПРОБЛЕМИ УПРАВЛІННЯ ПІДПРИСМСТВАМИ В УМОВАХ СВІТОВОЇ КРИЗИ
}

У статті встановлено, що перед сучасними підприємцями постає безліч ризиків. Важливим напрямком виходу з кризи, особливо, в умовах пандемії спричиненої COVID 2019, повинна бути підтримка держави, особливо харчових підприємств, які забезпечують продовольчу безпеку, отельного та ресторанного бізнесу, розважальний сектор та ін., які забезпечують надходження ВВП і покращують життя. Не зважаючи на те, що фахівці вважають, що харчова промисловість - одна із галузей, які страждають від кризи найменше, тим не менш, існують проблеми, з якими стикаються підприємці, і які висвітлені у статті. Підприємствам запропоновані шляхи можливого подолання кризового становища.

Ключові слова: управління в умовах кризи, якість харчової продукції, управління підприємствами, бізнес ризики, харчова промисловість, продовольча безпека.

Немченко Анна, ассистент,

Одесская национальная академия пищевых технологий, кафедра управления бизнесом,

г. Одесса

Колесникова Екатерина, кандидат экономических наук, доцент, Одесская национальная академия пищевых технологий, кафедра менеджмента и логистики, г. Одесса

Бондар Виктория, кандидат экономических наук, Одесская национальная академия пищевых технологий, кафедра менеджмента и логистики, г. Одесса

\section{ПРОБЛЕМЫ УПРАВЛЕНИЯ ПРЕДПРИЯТИЯМИ В УСЛОВИЯХ МИРОВОГО КРИЗИСА}


В статье установлено, что перед современными предпринимателями возникает множество рисков. Важным направлением выхода из кризиса, особенно в условиях пандемии вызванной COVID 2019, должна быть поддержка государства, главным образом, пищевых предприятий, обеспечивающих продовольственную безопасность, отельного и ресторанного бизнеса, развлекательный сектор и др., которые обеспечивают поступление ВВП и улучшают жизнь. Несмотря на то, что специалисты считают, что пищевая промышленность - одна из отраслей, которые страдают от кризиса меньше, тем не менее, существуют проблемы, с которыми сталкиваются предприниматели, и которые освещены в статье. Предприятиям предложены пути возможного преодоления кризисного положения.

Ключевые слова: управление в условиях кризиса, качество пищевой продукции, управление предприятиями, бизнес риски, пищевая промышленность, продовольственная безопасность.

\author{
Hanna Nemchenko, \\ Assistant Lecturer, \\ Odessa National Academy of Food Technologies, \\ Business Management Chair, \\ Odessa \\ Kateryna Kolesnikova, \\ PhD in Economics, Associate Professor, \\ Odessa National Academy of Food Technologies, \\ Management and Logistic Chair, \\ Odessa \\ Victoriya Bondar, \\ PhD in Economics, \\ Odessa National Academy of Food Technologies, \\ Management and Logistic Chair, \\ Odessa
}

\title{
MANAGEMENT PROBLEMS OF ENTERPRISES IN WORLD CRISIS
}

The article is dealt with, that there are plenty of risks in any industry. And managers have to solve different problems every day to stay relevant and profitable. It is a well-known fact that modern entrepreneurs want to become harmonious and successful. It is believed that successful business is the art of managing limited resources in conditions of constant risk and unlimited opportunities. Management of companies in any industry has its own nuances. For example, food enterprises. Managers of this industry must run their business and on the other hand there is strict liability because these enterprises ensured food security - one of the most important functions of the state. Risk is known to be a potential problem that can drive development or destroy a business. Thus, most scientists identify risks, like economic, political, reputational risks, the threat of losing competitive advantage, environmental, price, technical, investment, currency, legal and others. Therefore, it is extremely important for any entrepreneur to clearly identify all the risks associated with doing business to implement an effective business management system. Among the most significant risks, in 2020, entrepreneurs identify quarantine caused by the COVID 2019 virus (coronavirus disease). Overcoming the crisis in 2020 is mainly related to the fight against the pandemic and the support of health care facilities. However, other industries, especially the food industry, tourism, hotel, restaurant business, etc., also need support. An important direction in solving the problem should also be given to food security, improving the quality of food, quality of services, focus on the environment, which will address the effects of the crisis, increase GDP, and, consequently, improve welfare, emigration and unemployment, will improve life expectancy.

Key words: crisis management, food quality, enterprise management, business risks, food industry, food security.

Постановка проблеми. Перед сучасними підприємцями, які хочуть, щоб власний бізнес розвивався гармонічно та був прибутковим, постає безліч ризиків. Існує думка, що успішна підприємницька діяльність - це мистецтво управляти обмеженими ресурсами в умовах постійного ризику і необмежених можливостей. Управління підприємствами будь-якої галузі має свої нюанси. Особливо варто відзначити саме харчові підприємства, оскільки перед менеджерами стоїть жорстка відповідальність, тому що цими підприємствами забезпечується продовольча безпека - одна із 
важливих функцій держави. Відомо, що ризик є потенційною проблемою, яка може стати двигуном розвитку, або знищити бізнес. Так, більшість вчених виділяють ряд ризиків, серед яких: економічні, політичні, репутаційні ризики, загроза втратити конкурентні переваги, екологічні, цінові, технічні, інвестиційні, валютні, юридичні та ін. Тому, для будь-якого підприємця вкрай важливо чітко ідентифікувати всі ризики, пов'язані із здійсненням підприємницької діяльності, щоб впровадити ефективну систему управління бізнесом. Серед найбільш вагомих ризиків, у 2020 році, підприємці виділяють карантин, який спричинено вірусом COVID 2019 (коронавірус). Подолання кризи у 2020 році в основному пов'язують з боротьбою $з$ пандемією і підтримкою закладів охорони здоров'я. Однак, тим не менш, у підтримці потребують й інші галузі, особливо харчова промисловість, туристичний, отельний, ресторанний бізнес та ін. Важливим напрямком у вирішенні проблеми необхідно також приділити увагу питанню продовольчої безпеки, підвищення якості харчових продуктів, якості послуг, орієнтації на екологічність, що дозволить вирішити наслідки кризового становища, забезпечить зростання ВВП країни, i, відповідно, покращення добробуту населення, зниження показника еміграції і безробіття населення, покращить показник тривалості життя.

Аналіз останніх досліджень і публікацій. Проблема управління підприємствами знайшла відображення у різного роду дослідженнях М.П. Сичевського, Г. Поченцова, О. Орлова-Курилової та ін. У наукових працях Немченко В.В. йдеться мова про роль продовольчої безпеки в управлінні не лише підприємства, а і держави в цілому. Тим не менш, існує ряд проблем, які потребують вирішення, і відображені у даній статті.

Виділення невирішених раніше частин загальної проблеми. Незважаючи на значну кількість публікацій, які присвячено подоланню економічної кризи, шляхи управління бізнесом у кризовому становищі, як на прикладі кризи від пандемії коронавірусу, мало дослідженні. У першу чергу, необхідно приділити увагу заходам виходу з кризи, яка розпочалась у 2020 році. Особливо необхідно приділити увагу якості виробництва харчової продукції, як в Україні, так і у інших державах.

Виклад основного матеріалу. Підприємці кожен день стикаються з різними труднощами. Але, управління бізнесом в умовах кризових явищ - це мистецтво поєднання викликів і головної мети будь-якого підприємства - отримання прибутку. 3 одного боку, ризики є загрозою, але і з іншого рушійним джерелом бізнесу, можливостями і перспективами. Суспільство постійно постає перед глобальними викликами: забезпечити продовольчу, екологічну безпеку та рід інших аспектів. Але, у 2020 році, серед актуальних проблем додалась проблема подолання вірусу, який став пандемією i зупинив не просто ряд підприємств, а світові економіки. Отже, причиною економічної кризи у світі у 2020 році стала захворюваність на короновірус. У результаті боротьби з хворобою в усіх країнах, в тому числі і в Україна, зменшився ВВП. В оптимістичному сценарії Світової організації торгівлі, глобальна торгівля товарами знизиться на 13 відсотків порівняно з минулим роком. За обсягом експорт товарів знизиться на 17,1 відсотка в Північну Америку, на 13,5 відсотка в Азію та на 12,2 відсотки в Європу. Імпорт впаде відповідно на 14,5 відсотка, 11,8 відсотка та 10,3 відсотка.

У найгіршому випадку глобальна торгівля товарами знизиться на 32 відсотки порівняно з 2019. Це включає падіння експорту товарів з Північної Америки на 40,9 відсотка, з Азії на 36,2 відсотка та з Свропи на 32,8 відсотка. Імпорт знизиться на 33,8 відсотка до Північної Америки, 31,5 відсотка до Азії та 28,9 відсотка до Європи [1].

Щодо ситуації в Україні, то за оцінками офісу ефективного регулювання BRDO, то серед секторів економіки, в IT галузі зростання сповільниться, але тим не менш, через актуальність нових технологій, у допомозі виходу із кризи, ця галузь має істотні можливості для відновлення.

Постраждають телекомунікації, хоча і попит ця галузь не втратить, однак, спостерігається скорочення використання певних послуг, скорочення доходів від закриття магазинів, що призведе, до можливого подорожчання вартості послуг і призупиненню розгортання нових мереж.

В енергетиці прогнозовано, що через зменшення доходів впаде і рівень сплати за комунальні послуги. На приклад, у Києві на кінець березня рівень оплати $80 \%$, що є меншим за аналогічний період у минулих роках.

Металургія постраждає через падіння цін на нафту. Крім того, ціни на залізну руду залежать від цін обсягів експорту до Китаю, який також скоротився.

Інвестиції у розвиток значно скоротяться, що призведе до скорочення масштабу будівництва. 
На ринку праці, а також і підприємствах, які вимушені закрити свій бізнес на час карантину (ресторани, кінотеатри, розважальні заклади, туроператори, фітнес клуби, вантажні перевезення та ін.), виникне проблема 3 оплатою праці співробітників і пошуків ресурсів, для підтримки життєздатності бізнесу і населення на час карантину. Підприємства постануть перед вибором: відправляти персонал у неоплачувану відпустку чи звільняти людей, оскільки бізнес не готовий до таких випробувань.

Щодо сільського господарства, хоча і більшість вважає, що цю галузь криза зачепить не сильно, існує ряд викликів. По-перше, не зважаючи на попит на українську аграрну продукцію, спостерігається засуха, яка призведе до втрати значної частини врожаю. По-друге, падіння цін на нафту є поштовхом до зубожіння тих країн, значна частина багатства яких залежить від нафти. Серед цих країн, $є$ ті, які імпортують українську продукцію. Тому, можливо, різке скорочення експорту, i як наслідок - зменшення доходів українців [2,3,4].

Як вважав К. Маркс у ХIX столітті основою виходу з економічної кризи є оновлення основного капіталу. Сьогодні основою виходу 3 кризи є не тільки оновлення основного капіталу, але ще й вирішення соціальних проблем - охорони здоров'я, навколишнього середовища, забезпечення якісним продовольством та інші, які тісно взаємопов'язані між собою. Це передбачає створення нової сучасної структури економіки, формування інноваційно-соціальної моделі суспільства. В цих умовах зростає значення держави, яка повинна використовувати як ринкові так і неринкові важелі управління. Причому мова повинна йти про оптимізацію цих важелів управління. На жаль, такої оптимізації ми не завжди спостерігаємо. Так, наслідком боротьби з короновірусною інфекцією стало закриття ресторанного, туристичного бізнесу, транспорту, деяких видів торгівлі та промисловості. Заходи держави, які стосуються кредитування (зниженню відсотків), на нашу думку, мало буде сприяти зростанню економіки в Україні. Пільгове кредитування повинно надаватись в першу чергу інноваційним та соціальним напрямкам. Згортання фінансової підтримки АПК, місцевих бюджетів та інших соціальних напрямків робить проблематичним взагалі вихід з кризи.

Важливим напрямком виходу 3 кризи в умовах пандемії повинна бути підтримка держави не тільки закладів охорони здоров'я, але й харчових підприємств, від продукції яких залежить тривалість життя. Ось чому, сучасна держава повинна підтримувати виробництво екологічної, якісної, інноваційної харчової продукції.

Як вважає Орлова-Курилова О., при динамічних змінах у зовнішньому середовищі складноорганізована, система інноваційного підприємництва знаходиться у постійній напрузі, що неминуче призводять до порушення стабільності усієї системи, виникнення хаосу й, відповідно, пошуку системою резервів як усередині так із зовні, для поліпшення свого стану. У такому стані підвищуються потреби системи до інновацій, завдяки яким можливо удосконалити її структуру й вивести на новий, більш високий рівень інноваційного розвитку. Ми повністю розділяємо цю думку [5].

В першу чергу, вважаємо, що необхідні інновації в управлінні харчовим бізнесом. Як вже йшла мова, що саме цей сектор забезпечує продовольчу безпеку, яка представляє собою не лише кількісній вимір продуктів харчування, але і якісний. Нині, якісний фактор є недорозвиненим.

Забезпечення населення харчовими продуктами - найважливіша проблема у XXI столітті, вирішення якої впливає на рівень та якість життя населення, зростання ВВП. По відношенню вартості харчових продуктів, які споживають домогосподарства, до зарплати (або доходу) визначають економічну доступність продовольства і рівень життя населення. Так, у розвинутих державах харчові продукти займають незначну частку у бюджеті населення. У країнах з перехідною економікою витрати на продовольство становлять більше половини сімейного бюджету, що на нашу думку, не завжди достатньо розкриває його доступність для населення, оскільки ще залежить, i, від цін на інші товари, необхідні для підтримки життя. Особливо в умовах кризи, спричиненою пандемією, більшість населення стає на порозі бідності, у деяких випадках не має фінансових ресурсів, для забезпечення себе предметів першої необхідності. Так, в Україні підвищення цін на житлово-комунальні платежі, високий рівень інфляції, сприяло зниженню купівельної спроможності населення, включаючи харчові продукти, що супроводжувалось збільшенням захворюваності, смертності. У деяких випадках, у сільській місцевості, все це ще сприяло знищенню лісосмуг, тому що населення використовувало дрова для опалення для економії газу. Це свою чергу погіршує 
екологічне становище, створює загрозу майбутнім врожаям i підйому життєвого рівня. У цих умовах населення України вимушена орієнтуватися лише на дешеві, не завжди якісні харчові продукти. Тому, харчова промисловість незацікавлена випускати якісну продукцію для національного продовольчого ринку. Низька якість харчової продукції викликана i тим, що сільськогосподарська сировина не завжди відповідає сучасним вимогам. Пов'язано таке становище 3 тим, що економіка України характеризується багатоукладністю, існуванням доринкових форм господарювання. Мова йде в першу чергу про особисті підсобні господарства, які суперечать розвитку суспільства у XXI столітті, не мають ні технічних, ні фінансових можливостей для достатнього виробництва екологічно безпечної, якісної продукції. На нашу думку, в цих умовах виникає потреба кооперації особистих господарств, що з одного боку збільшить їх фінансові можливості, використовувати екологічні технології, а 3 іншого дозволить контролювати виробництво державою, регіонами та споживачами харчової продукції. При чому кооперація повинна бути «пов'язана» 3 переробними харчовими підприємствами, що дозволить отримувати додану вартість, створювати робочі місця, випускати якісну продукцію, а не експортувати на зовнішні ринки сировину.

Слід відзначити, що низька якість харчової продукції спостерігається не тільки в слаборозвинутих країнах, але й у ЄС, де наприклад, на початку 2019 року був заборонено експорт яловичини з Польщі, яка мала загрозу для здоров'я споживачів.

У березні 2019 року в Уганді отруїлись 160 людини і 2 померли від споживання зернових культур, які надавались Всесвітньою продовольчою програмою ООН. Це свідчить, що у кожній країні існують «свої» стандарти, які іноді не відповідають міжнародним. Не випадково професор Немченко В.В. визначає продовольчу безпеку, як «здатність задовольняти потреби населення в продовольстві в умовах обмежених фінансових, екологічних можливостей держави згідно з науковообгрунтованими нормами, індивідуальних особливостей людини та їі платоспроможності на рівні цін. Таке визначення продовольчої безпеки значно ширше і свідчить, що ії ще не досягли майже усі країни світу» [6, с.180]. Ось чому, і якість харчових продуктів в усіх країнах ще не досягла науковообгрунтованих норм споживання з урахуванням особливостей конкретної людини.

Великі фірми, використовуючи сенсорний аналіз розробляють і виробляють такі харчові продукти, які відповідають смаковим запитам населення регіону, роблячи його залежним споживачем. При чому, виробники створюють дослідницькі фонди, за допомогою яких і реклами впливають масовій свідомості. Наприклад, виробники солодких напоїв доказують, що не цукор веде до ожиріння, а відсутність фізичних навантажень [7]. Породжуючи сумнів у споживача, це виробляє у нього залежність від цих напоїв і одночасно сприяє розвитку діабету, але це не заважає таким харчовим підприємствам отримувати прибуток. Як справедливо вважає М.М. Бердар, що «харчові продукти повинні не просто задовольняти їх смаковим уподобанням, а і бути екологічними, безпечними, органічними чи медично корисними» [9, с12]. Одним із напрямків вирішення цієї проблеми, на думку автора, $\epsilon$ фортифікація продуктів харчування. Вона дозволяє збільшити зміст вітамінів та мікроелементів у продуктах харчування заради покращення поживних якостей їжі та позитивного ефекту для здоров'я людей.

Все це свідчить, що у XXI столітті змінюється функція держави на аграрному ринку. Вона виступає не тільки як «нічний вартовий», а управління «невидимої руки» повинно бути доповнено економічними та правовими важелями, які би впливали не тільки на пропозицію якісної продовольчої продукції, але і допомагало формувати у населення відповідний попит, тому що від цього залежить тривалість життя, зростання економіки. Тому, в управлінні виробництвом i контролем якісної харчової продукції, забезпеченні продовольчої безпеки повинні приймати участь регіони та держава. Відсутність такого управління буде сприяти зменшенню трудового потенціалу регіонів (кількісного та якісного), ВВП країни, збільшенню витрат на охорону здоров'я населення, зменшенню якості земельних ресурсів.

Все це підтверджує, що сьогодні повинна здійснюватися орієнтація на виробництво екологічних харчових продуктів, розробляти такі інгредієнти яких були би корисні для людини. Це передбачає «союз» харчової промисловості і охорони здоров'я. Безумовно визначити вплив того або іншого харчового продукту, його в першу чергу, якості та стан здоров'я досить важка задача, тому що сьогодні ще відсутні відповідні дослідження. Не випадково Царенко О.М. ще у 1999 році писав: 
«Контроль якісного складу продуктів харчування не вирішує проблему гарантії виробництва нешкідливої продукції, оскільки не дає системних знань про наслідки споживання тієї або іншої продукції як у складової частини взаємодії організму і середовища проживання [8, с.21]. Слід звертати увагу на слова президента асоціації "Український клуб аграрного бізнесу" Алекса Ліссітси: "Український аграрний експорт є значною частиною всього українського експорту - більше 20 млрд доларів щорічно, і тому навіть падіння на $10 \%, 15 \%$, або $20 \%$ може становити до мінус 4 млрд доларів валютних надходжень до державної скарбниці. А це досить суттєвий показник для нашої слабкої економіки".

Щодо ситуації з готелями, авіакомпаніями, розважальними закладами, ресторанами і тд., то ситуація аналогічна: найбільше постраждають сфери бізнесу, на діяльність яких накладаються безпосередні обмеження у зв'язку з введенням карантинних заходів:

- розважально-культурні заклади (театри, кінотеатри, виставки, різноманітні розважальні заходи, фітнес-клуби тощо) та готельно-ресторанний бізнес - від повної зупинки до спаду виручки на $50-80 \%$;

- туристичні послуги - абсолютне падіння у період карантину у зв'язку із закриттям кордонів України;

- сфера надання косметологічних послуг - вже спад відвідувачів більш ніж на 50\% [10].

Саме тому, особливо у такій ситуації, необхідна державна підтримка бізнесу.

По-перше, пропонується зменшити податкове навантаження і звільнити від сплати податків у карантинний період ті підприємства, які вимушені закритися.

По-друге, надавати пільгове кредитування під інноваційні проєкти.

По-третє, не зважаючи на кризу, стимулювати адаптуватися бізнес до сучасних викликів, використовуючи інноваційні та екологічні принципи.

Тому, вважаємо, якщо ці міри будуть застосовуватися, то вихід з кризової ситуації пройде легше і швидше, держава зможе відновити роботу підприємств.

Висновки та пропозиції. У XXI столітті основою виходу з кризи стає не тільки оновлення основного капіталу, але ще й вирішення соціальних проблем. Важливим напрямком виходу з кризи в умовах пандемії повинна бути підтримка держави не тільки закладів охорони здоров'я, але й харчових підприємств, від продукції яких залежить тривалість життя.

Виникає потреба в кооперації особистих господарств, що з одного боку збільшить їх фінансові можливості використовувати екологічні технології, а з іншого дозволить контролювати виробництво державою, регіонами та споживачами харчової продукції. При чому кооперація повинна бути «пов'язана» 3 переробними харчовими підприємствами, що дозволить отримувати додану вартість, створювати нові робочі місця, випускати якісну продукцію, а не експортувати на зовнішні ринки сировину.

Країна ще не відновилась після кризи 2009 року. На жаль, вітчизняний агропромисловий сектор виробляє найпростіші аграрні продукти 3 низькою доданою вартістю. Більшість підприємств зупинило роботу і не мають фінансових ресурсів для подолання кризи. Тому, для стабілізації, запропоновано ряд заходів, які допоможуть вийти із кризи і у майбутньому забезпечити ріст ВВП, сприятиме покращенню добробуту і якості життя населення.

\section{Джерела та література}

1. The Coming Decline of Global Trade [Електронний ресурc]:- Режим доступу: https://geopoliticalfutures.com/the-coming-decline-of-global-trade/
2. Економіка буде сидіти вдома. [Електронний https://businessviews.com.ua/ru/business/id/jak-karantin-vplivaje-na-biznes-2159/

3. Вплив економічної кризи на ключові сфери та ринки: оцінка BRDO. [Електронний ресурс]:- Режим доступу: https://brdo.com.ua/analytics/vplyv-ekonomichnoyi-kryzy-na-klyuchovi-sfery-ta-rynky-otsinka-brdo/

4. Тепла зима і суха весна: українські аграрії бояться втратити врожай. Deutsche Welle. [Електронний pecypc]:- Режим доступу: https://www.dw.com/uk/tepla-zyma-i-sukha-vesna-ukrainski-ahrarii-boiatsia-vtratytyvrozhai/a-53004803 
5. Орлова-Курилова О. Методологічні підходи до аналізу інноваційних процесів у підприємництві. Економічний часопис Східноєвропейського начіонального університету імені Лесі Украӥнки. 2020, №1, С.80-86. DOI: https://doi.org/10.29038/2411-4014-2020-01-80-86

6. Немченко В.В. Продовольча безпека України. Збірник наукових праць ВНАУ. Серія: Економічні науки. 2012. № 4 (70) Т.2, С.179 - 182.

7. Поченцов Г. Управляя коммуникацией, мы одновременно управляем миром. Дзеркало тижня. [Електронний ресурс] :- Режим доступу: https://zn.ua/socium/upravlyaya-kommunikaciey-my-odnovremennoupravlyaem-mirom-309839_html

8. Бердар М.М. Конкурентоспроможність підприємств харчової промисловості України: сучасні проблеми та напрями підвищення. Агросвіт. 2018. № 12, С.8-14.

9. Сичевський М.П. Харчова промисловість як основа продовольчої безпеки та розвитку держави. К.: Аграрна наука. 2019. 388 с.

10. Бізнес в Польщі в умовах пандемії коронавірусу (COVID-2019). [Електронний ресурс]:- Режим доступу: https://blog.liga.net/user/mromanyuk/article/36285

\section{References}

1. The Coming Decline of Global Trade. geopoliticalfutures.com Retrieved from: https://geopoliticalfutures.com/the-coming-decline-of-global-trade.

2. Ekonomika bude sydity vdoma. [The economy will stay home] businessviews.com.ua. Retrieved from: https://businessviews.com.ua/ru/business/id/jak-karantin-vplivaje-na-biznes-2159 [ in Ukrainian].

3. BRDO's analysis: the impact of the economic crisis on key areas and markets. brdo.com.ua. Retrieved from: https://brdo.com.ua/analytics/vplyv-ekonomichnoyi-kryzy-na-klyuchovi-sfery-ta-rynky-otsinka-brdo/

4. Tepla zyma i sukha vesna: ukrajinsjki aghrariji bojatjsja vtratyty vrozhaj. [Warm winter and dry spring: Ukrainian farmers are afraid of losing the harvest]. Deutsche Welle. Retrieved from: https://www.dw.com/uk/teplazyma-i-sukha-vesna-ukrainski-ahrarii-boiatsia-vtratyty-vrozhai/a-53004803 [ in Ukrainian].

5. Orlova-Kurilova Olga (2020). Metodologhichni pidkhody do analizu innovacijnykh procesiv u pidpryjemnyctvi. [Methodological approaches to analysis of innovation processes in entrepreneurship]. Ekonomichnyj chasopys Skhidnojevropejsjkogho nacionaljnogho universytetu imeni Lesi Ukrajinky. - Economic Journal of the Lesia Ukrainka East European National University. 2020, 1, 80-86. DOI: https://doi.org/10.29038/2411-4014-2020-01-8086 [ in Ukrainian].

6. Nemchenko Valerii (2012). Prodovoljcha bezpeka Ukrajiny [Ukrainian food safety]. Zbirnyk naukovykh pracj VNAU. Serija: Ekonomichni nauky. - Collection of scientific works of VNAU. Series: Economic Sciences № 4 (70) V. 2, $179-182$. [ in Ukrainian].

7. Pochencov Gh. (2020) Upravljaja kommunykacyej, mы odnovremenno upravljaem myrom. [Managing communication, we simultaneously control the world]. Dzerkalo tyzhnja. Retrieved from: https://zn.ua/socium/upravlyaya-kommunikaciey-my-odnovremenno-upravlyaem-mirom-309839_.html [in Russian].

8. M. Berdar (2018). Konkurentospromozhnistj pidpryjemstv kharchovoji promyslovosti Ukrajiny: suchasni problemy ta naprjamy pidvyshhennja. [Competitiveness of food industry enterprises of Ukraine: modern problems and directions of improvement]. Agrosvit. (12), 8-14. [ in Ukrainian].

9. Sychevsjkyj M.P. (2019). Kharchova promyslovistj jak osnova prodovoljchoji bezpeky ta rozvytku derzhavy. [Food industry as a basis for food security and state development]. Aghrarna nauka - Agricultural science, 388 [ in Ukrainian].

10. Biznes v Poljshhi v umovakh pandemiji koronavirusu (COVID-2019). [Business in Poland in the context of the coronavirus pandemic (COVID-2019)] blog.liga.net. Retrieved from: https://blog.liga.net/user/mromanyuk/article/36285 [ in Ukrainian]. 